\title{
PENGARUH SIKAP, NORMA SUBYEKTIF DAN HALAL IMAGE TERHADAP NIAT CALON NASABAH MENGGUNAKAN PRODUK PERBANKAN SYARIAH PADA BANK NEGARA INDONESIA SYARIAH (BNIS) CABANG LHOKSEUMAWE
}

\author{
Khairawati*, Fuadi**, Munandar*** \\ *Dosen Fakultas Ekonomi Dan Bisnis Universitas Malikussaleh
}

\begin{abstract}
This study aims to determine the effect of Attitude, Subjective Norms, and Halal image either partially or simultaneously on the intention of prospective customers to use Islamic banking products at the Bank Negara Indonesia Syariah (BNIS) Lhokseumawe branch and to find out the most dominant factors in influencing prospective customer intentions. The results showed that attitude, subjective norms, and Halal image were simultaneously significant in influencing the intention of prospective customers to use Islamic banking products. Partially each of the Attitude, Subjective Norms, and Halal image variables influence the intention of prospective customers to use Islamic banking products. Attitude variable is the most dominant variable in influencing the intention of prospective customers to use Islamic banking products.
\end{abstract}

Keywords: Attitude, Subjective Norms, Halal Image, and Intention.

\section{PENDAHULUAN}

Perkembangan bisnis dewasa ini khususnya perbankan kini semakin berkembang, terbukti dengan banyaknya jumlah bank dan jenis usaha perbankan lainnya yang beroperasi hampir di setiap daerah yang semakin hari semakin menarik minat konsumen. Salah satu dari berbagai jenis perbankan adalah perbankan dengan prinsip syariah. Perbankan syariah telah mendapat tempat tersendiri dalam pandangan masyarakat, terutama bagi mereka yang muslim sehingga secara tidak langsung menciptakan segmen pasar tersendiri. Seiring berjalan waktu dan dengan semakin prospektifnya kondisi ekonomi nasional dan membaiknya pendapatan masyarakat telah menimbulkan perebutan pangsa nasabah yang terus meningkat di sektor ini.

Dengan persaingan yang begitu kompetitif, perusahaan perbankan syariah 
melakukan berbagai upaya pemasaran untuk menarik nasabah sebanyak-banyaknya. Berdasarkan fakta dan teori-teori pada umumnya, konsumen akan memilih produk/ jasa dengan melihat atribut-atribut yang diyakininya relevan dengan yang dibutuhkannya. Untuk itu produsen perbankan syariah perlu mengetahui bagaimana konsumen menilai atribut - atribut dari produk/jasa yang dihasilkan. Hal ini dikarenakan penilaian dari konsumen tersebut akan mempengaruhi niat konsumen dalam memilih jasa perbankan syariah.

Niat adalah salah satu faktor internal (Individu) yang dapat mempengaruhi perilaku konsumen untuk melakukan pembelian. Dalam proses pembelian, niat beli konsumen ini berkaitan erat dengan motif yang dimilikinya untuk memakai ataupun membeli produk tertentu. (Sigit 2006 : 82). Supaya nasabah memiliki persepsi dan perasaan positif terhadap produk/jasa yang dikeluarkan perusahaan perbankan syariah, maka produk/jasa tersebut harus benar-benar memiliki costumer value yang baik dan menguntungkan dimata nasabah serta membedakannya dengan produk/jasa pesaing.

Niat seseorang dalam membeli produk/jasa merupakan hal yang dipengaruhi oleh sikap seseorang terhadap perilaku pembelian serta norma subyektif. Hal tersebut sejalan dengan pendapat Ajzen \& Cote (2008) yang mengatakan bahwa niat berperilaku itu dapat diketahui dengan memperkirakan sikap terhadap perilaku dan norma subyektif. Berdasarkan Theory of Reasoned Action dari Fishbein dan Ajzen, tindakan seseorang adalah realisasi dari keinginan atau niat seseorang untuk bertindak. Faktor yang mempengaruhi niat adalah sikap pada tindakan, dan norma subyektif menyangkut persepsi seseorang, apakah orang lain yang dianggap penting akan mempengaruhi perilakunya (Dharmmesta, 1998 : 89).

Menurut Schiffman dan Kanuk (2004 : 79) kesadaran manusia merupakan pengetahuan dan persepsi yang diperoleh dari pengalaman langsung dengan sikap obyek dan informasi lain dari berbagai sumber. Selanjutnya informasi ini diolah dan proses pengolahan ini sangat berkaitan dengan sikap konsumen.

Menurut Mowen dan Minor (2001: 319) definisi yang tepat dalam menggambarkan sikap adalah seperti yang dikemukakan oleh L.L. Thurstone yang mendefinisikan sikap sebagai "afeksi atau perasaan untuk atau terhadap sebuah rangsangan". Selain sikap dapat mendasari minat beli konsumen, faktor norma subyektif (subjective norms) juga dapat mempengaruhi niat beli konsumen. Menurut Ajzen \& Driver (1991) Norma subyektif merupakan persepsi individu berhubungan dengan kebanyakan dari orang-orang yang penting bagi dirinya mengaharapkan individu untuk melakukan atau tidak melakukan tingkah laku tertentu, orang - orang yang penting bagi dirinya itu kemudian dijadikan acuan atau patokan untuk mengarahkan tingkah laku. 
Kemudian, dalam sejumlah penelitian yang dilakukan oleh para pakar ditemukan brand image mempengaruhi perilaku konsumen dalam memilih produk. Halal images pada dasarnya adalah Brand Images yang spesifik atau sub dari keseluruhan citra merek yang terbentuk dalam benak seseorang. Halal images didefinisikan sebagai persepsi konsumen terhadap suatu karakteristik merek yang dipertahankan dalam ingatan seseorang sebagai konsep keagamaan yang membimbingnya kepada pola pembelian mendasar. Karena berdasarkan konsep ajaran Islam, pola pembelian ini merupakan pusat kehidupan sehari-hari umat Islam. Mohd Suki \& Abang Salleh (2016).

Berbicara mengenai kompetitor, pada segmen perbankan syariah di Aceh khususnya sekarang ini begitu banyak dan sangat kompetitif, BNI Syariah akan menghadapi kopetitor seperti Mandiri Syariah, Muamalat, Mega Syariah dan Lainnya, yang tentunya perusahaan-perusahaan kompetitor ini memiliki pengalaman yang cukup baik dan sangat kompetitif. Oleh karena itu BNI Syariah dituntut untuk terus dapat bersaing dengan kompetitor-kompetitor yang sangat agresif dalam gerilya pemasaran. Tentunya sudah menjadi keharusan bagi BNI Syariah untuk dapat mendesain produk/jasa yang dapat bersaing dengan kompetitor-kompetitor yang tersebut di atas.

\section{TINJAUAN TEORITIS}

\section{Sikap Konsumen}

Menurut Mowen dan Minor (2001: 319) definisi yang tepat dalam menggambarkan sikap adalah seperti yang dikemukakan oleh L.L. Thurstone yang mendefinisikan sikap sebagai "afeksi atau perasaan untuk atau terhadap sebuah rangsangan". Penggunaan kata sikap yang mengacu pada afeksi atau reaksi evaluatif umum merupakan hal yang biasa di antara para peneliti perilaku konsumen saat ini. Selanjutnya Mowen dan Minor menambahkan beberapa definisi terbaru dari para pakar terhadap sikap, yaitu : Sikap merupakan kategorisasi objek pada rangkaian kesatuan evaluatif, Karakteristik utama yang membedakan sikap dari konsep lainnya adalah sifat evaluatif atau afektif, Sikap merupakan inti dari rasa suka dan tidak suka bagi orang, kelompok, situasi, objek, dan ide-ide tidak berwujud tertentu. Menurut Ajzen \& Fishbein (1975), sikap adalah disposisi untuk berespon secara favorable atau unfavorable terhadap benda, orang, intuisi atau kejadian. Selanjutnya Schiffman dan Kanuk (2004: 222) memberikan pengertian sikap sebagai kecenderungan yang dipelajari dalam berperilaku dengan cara yang menyenangkan atau tidak menyenangkan terhadap suatu objek tertentu. Menurut Kotler dan Armstrong (2008:220) sikap merupakan evaluasi, perasaan, dan kecenderungan yang konsisten atas suka atau tidak sukanya seseorang terhadap objek atau ide. 


\section{Norma Subyektif}

Menurut Azjen \& Driver (1991) Norma subyektif adalah perasaan atau pendugaan seseorang terhadap harapan-harapan dari orang-orang yang ada dalam kehidupannya mengenai dilakukan atau tidak dilakukan perilaku tertentu. Sejalan dengan itu Peter dan Olson (2000: 150) mengatakan bahwa norma subyektif atau sosial mencerminkan persepsi konsumen tentang apa yang mereka anggap bahwa orang lain agar mereka lakukan. Norma subjektif mencerminkan persepsi konsumen tentang apa yang mereka anggap bahwa orang lain ingin agar mereka melakukan perilaku khusus. Keyakinan normatif utama konsumen sehubungan dengan "melakukan apa yang orang lain ingin mereka lakukan" dan motivasi untuk memenuhi harapan orang lain tersebut dikomuninasikan untuk membentuk norma subjektif. Norma subjektif memiliki dua komponen yaitu keyakinan normatif dan motivasi.

\section{Halal Image}

Halal images pada dasarnya adalah Brand Images yang spesifik atau sub dari keseluruhan citra merek yang terbentuk dalam benak seseorang. Halal images didefinisikan sebagai persepsi konsumen terhadap suatu karakteristik merek yang dipertahankan dalam ingatan seseorang sebagai konsep keagamaan yang membimbingnya kepada pola pembelian mendasar. Karena berdasarkan konsep ajaran Islam, pola pembelian ini merupakan pusat kehidupan sehari-hari umat Islam. Mohd Suki \& Abang Salleh (2016). Sementara menurut Ali et al (2018) halal images merupakan seperangkat persepsi merek dalam benak pelanggan yang terkait dengan keimanan seorang muslim, kepedulian pada kehalalan serta komitmen akan halal. Lebih lanjut Ali et al (2018) menambahkan sebagaimana dengan peran citra merek untuk produk tradisional, citra merek produk Halal dapat menciptakan nilai bagi perusahaan karena dapat memudahkan konsumen mencari informasi produk halal, dan juga dapat membantu menciptakan asosiasi yang memperoleh perasaan dan sikap positif yang berdampak ke produk lain dengan merek yang sama.

\section{Niat Konsumen}

Teori niat beli konsumen didasari oleh teori alasan bertindak (Ajzen \& Fishbein 1975). Teori ini mengasumsikan bahwa konsumen selalu mempertimbangkan secara sadar konsekuensi dari pemilihan alternatif yang berakibat keinginan (niat) untuk melakukan/bertindak sesuai dengan pilihan perilaku. Niat beli ini merupakan prediktor tunggal terbaik terhadap perilaku sesungguhnya. Ajzen \& Fishbein (1975) mengartikan niat sebagai disposisi tingkah laku, yang hingga terdapat waktu dan kesempatan yang tepat, akan diwujudkan dalam bentuk tindakan. Ajzen \& Fishbein (1975) menambahkan dengan menyatakan bahwa niat seseorang untuk melakukan suatu perilaku 
menentukan akan dilakukan atau tidak dilakukannya perilaku tersebut. Lebih lanjut, Ajzen mengemukakan bahwa niat melakukan atau tidak melakukan perilaku tertentu dipengaruhi oleh dua penentu dasar, yang pertama berhubungan dengan sikap (attitude towards behavior) dan yang lain berhubungan dengan pengaruh sosial yaitu norma subjektif (subjective norms). Dalam upaya mengungkapkan pengaruh sikap dan norma subjektif terhadap niat untuk dilakukan atau tidak dilakukannya perilaku, Ajzen melengkapi dengan keyakinan (beliefs). Dikemukakannya bahwa sikap berasal dari keyakinan terhadap perilaku (behavioral beliefs), sedangkan Norma subjektif berasal dari keyakinan normatif (normative beliefs).

Adapun kerangka teoritis penelitian ini dapat diperlihatkan pada gambar di bawah ini :

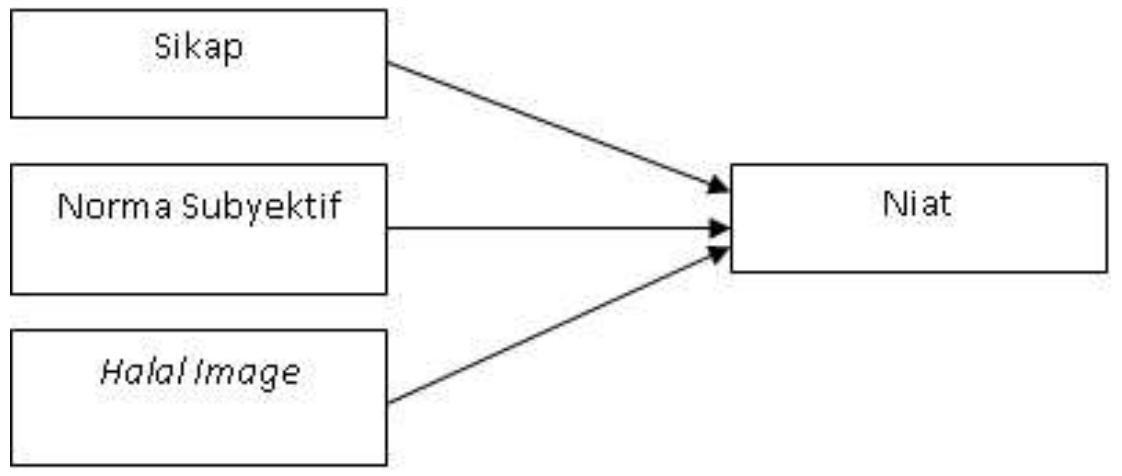

\section{Gambar 1. Kerangka Konseptual}

\section{Hipotesis}

Hipotesis adalah dugaan sementara dari suatu penilaian yang harus diuji kebenarannya. Berdasarkan rumusan masalah dan uraian sebelumnya maka hipotesis yang dikemukakan disini adalah:

H1: $\quad$ Diduga Sikap berpengaruh positif terhadap Niat Calon Nasabah menggunakan produk perbankan syariah pada Bank Negara Indonesia Syariah (Bnis) cabang Lhokseumawe

H2: Diduga Norma Subyektif berpengaruh positif terhadap Niat Calon Nasabah menggunakan produk perbankan syariah pada Bank Negara Indonesia Syariah (Bnis) cabang Lhokseumawe

H3: Diduga Halal Image berpengaruh positif terhadap Niat Calon Nasabah menggunakan produk perbankan syariah pada Bank Negara Indonesia Syariah (Bnis) cabang Lhokseumawe 


\section{METODE}

Sebagai lokasi penelitian untuk memperoleh data dan keperluan lainnya, peneliti mengadakan penelitian di Kota Lhokseumawe. Objek dalam penelitian ini adalah sikap, norma subyektif, dan halal images terhadap niat calon nasabah menggunakan produk perbankan syariah pada BNI Syariah. Sedangkan ruang lingkup penelitian ini adalah responden yang dijadikan sampel dalam penelitian ini yaitu masyarakat Kota Lhokseumawe yang belum pernah menggunakan produk/jasa perbankan syariah pada BNI Syariah.

\section{Populasi dan Sampel}

Populasi dalam penelitian ini adalah para masyarakat yang berada di Kota Lhokseumawe yang memungkinkan dan relevan untuk diambil data. Dalam penelitian ini penentuan besarnya jumlah sampel yang diambil oleh peneliti mengacu pada pendapat yang dikemukakan Birn (2000:149), yaitu bahwa dalam studi sosial secara kuantitatif diperbolehkan menggunakan jumlah sampel antara 100 sampai dengan 200. Jadi dalam penelitian ini peneliti menetapkan besarnya jumlah sampel sebanyak 150 orang. Hal ini disesuaikan dengan kemampuan peneliti dalam aspek waktu, dana dan lain sebagainya. Teknik penarikan sampel menggunakan teknik non probability sampling dengan pendekatan convenience sampling.

\section{Instrumen Penelitian}

Pengumpulan data dalam penelitian ini dilakukan dengan menggunakan kuesioner, yang disampaikan secara langsung oleh peneliti kepada para responden dalam hal ini masyarakat yang berada dalam wilayah Kota Lhokseumawe. Setelah kuesioner selesai diisi oleh responden, peneliti mengambil kembali kuesioner tersebut untuk selanjutnya ditabulasikan dan diolah. Lama waktu yang digunakan responden dalam mengembalikan kuesioner berbeda-beda, namun rata-rata responden mengembalikannya kurang dari 1 minggu. Untuk mengukur masing-masing variabel digunakan skala likert 1-5. Indikator pengukuran untuk variabel Sikap ( 3 item pertanyaan) mengacu pada Kaaeeh et al (2019), untuk variabel Norma Subyektif (3 item pertanyaan) diadopsi dari Lada et al (2009), variabel Halal Image (4 item Pertanyaan) mengacu pada Ali et al (2018), sementara variabel Niat merujuk pada Fishbein dan Ajzen (1975) dan Jasman (2005)

\section{Peralatan Analisis Data}

Dalam penelitian ini peralatan analisis data yang digunakan adalah analisis Regresi Linear Berganda. Selanjutnya akan dilengkapi dengan Koefisien Korelasi dan Determinan. Agar hasil analisis menjadi bermakna, maka dilakukan prosedur pengujian 
dengan pendekatan uji-t (parsial) dan uji-F (serentak).

\section{HASIL DAN PEMBAHASAN}

\section{Uji Validitas}

Pengujian validitas data dalam penelitian ini dilakukan secara statistik, yaitu dengan menggunakan uji Pearson Product-Moment Coeffisient of Corelation. Untuk mengetahui tingkat validitas dapat dilihat pada keseluruh item memiliki corrected Item-Total Correlation > 0,50 (Sugiyono, 2013). Dari hasil yang telah didapat, dapat disimpulkan bahwa indikator-indikator independent dan dependent variable dinyatakan valid. Hasil uji validitas dapat dilihat pada table 1 dibawah ini :

Tabel 1 Uji Validitas

\begin{tabular}{|c|c|c|c|c|}
\hline \multicolumn{2}{|c|}{$\begin{array}{l}\text { Indikator Pertanyaan Variabel } \\
\text { Independen } \\
\left(\mathrm{X}_{1}, \mathrm{X}_{2}, \mathrm{X}_{3}\right) \text {, dan } \\
\text { dependen }(\mathrm{Y})\end{array}$} & Pearson Correlation & Korelasi Minimal & Ktr \\
\hline \multirow[t]{4}{*}{ Variabel $X_{1}$} & Sikap & & & \\
\hline & $X_{1} \cdot 1$ & 0,773 & $>0,50$ & Valid \\
\hline & $X_{1} \cdot 2$ & 0,617 & $>0,50$ & Valid \\
\hline & $x_{1} 3$ & 0,792 & $>0,50$ & Valid \\
\hline \multicolumn{5}{|c|}{ Variabel $X_{2}$ Norma SUbyektif } \\
\hline & $X_{2} \cdot 1$ & 0,781 & $>0,50$ & Valid \\
\hline & $X_{2} \cdot 2$ & 0,820 & $>0,50$ & Valid \\
\hline & $x_{2.3}$ & 0,838 & $>0,50$ & Valid \\
\hline \multirow[t]{5}{*}{ Variabel $X_{3}$} & Halal Image & & & \\
\hline & $X_{3} \cdot 1$ & 0,798 & $>0,50$ & Valid \\
\hline & $X_{3} \cdot 2$ & 0,881 & $>0,50$ & Valid \\
\hline & $x_{3} 3$ & 0,864 & $>0,50$ & Valid \\
\hline & $x_{3} 4$ & 0,784 & $>0,50$ & Valid \\
\hline
\end{tabular}




\begin{tabular}{|c|c|c|c|}
\hline $\begin{array}{lr}\text { Variabel Y } & \text { Niat } \\
\mathrm{Y}_{1} & \mathrm{Y}_{2} \\
\mathrm{Y}_{3} & \\
\mathrm{Y}_{4} & \end{array}$ & $\begin{array}{l}0,766 \\
0,755 \\
0,721 \\
0,691\end{array}$ & $\begin{array}{l}>0,50 \\
>0,50 \\
>0,50 \\
>0,50\end{array}$ & $\begin{array}{l}\text { Valid } \\
\text { Valid } \\
\text { Valid } \\
\text { Valid }\end{array}$ \\
\hline
\end{tabular}

Sumber : Data Primer 2019 (diolah)

\section{Uji Reliabilitas}

Uji Reliabilitas menunjukkan konsistensi dan stabilitas dari suatu skor (skala pengukuran). Suatu instrumen dapat memiliki tingkat kepercayaan yang tinggi (konsisten) atau stabil dari waktu ke waktu (Ghozali, 2009). Acuan tingkat reliabilitas yang digunakan dalam penelitian ini merujuk pada pendapat Ghozali (2009) yang menunjukkan bahwa konstruk atau variabel dapat dikatan reliabel jika memilik nilai Cronbach Alpha > 0,60.

Dari hasil data yang diolah melalui SPSS dapat disimpulkan bahwa keseluruhan variabel yang diteliti sudah reliabel. Hasil uji Reliabilitas dapat dilihat pada table 2 dibawah ini :

Tabel 2 Uji Validitas

\begin{tabular}{|llccc}
\hline No & Variabel & Jumlah Indikator & Cronbach Alpha & Ktr \\
\hline 1 & Sikap $\mathrm{X}_{1}$ & 3 & 0,821 & Reliabel \\
2 & ${\text { Norma Subyektif } \mathrm{X}_{2}}_{3}$ & 3 & 0,794 & Reliabel \\
5 & Halal Image X & 4 & 0,728 & Reliabel \\
& Niat $\mathrm{Y}$ & 4 & 0,812 & Reliabel \\
\hline
\end{tabular}

Sumber : Data Primer 2019 (diolah)

\section{Pengujian Asumsi Klasik}

\section{Uji Normalitas}

Uji normalitas digunakan untuk menguji apakah dalam model regresi, variable pengganggu atau residual memiliki distribusi normal. (Ghozali, 2009). Cara untuk mendetekeksi apakah residual berdistribusi normal atau tidak yaitu dengan analisis 
gambar berupa plot. Berikut adalah hasil dari olah data yang dilakukan dari uji normalitas, dapat dilihat pada gambar 2 berikut:

Normal P-P Plot of Regression Standardized Residual

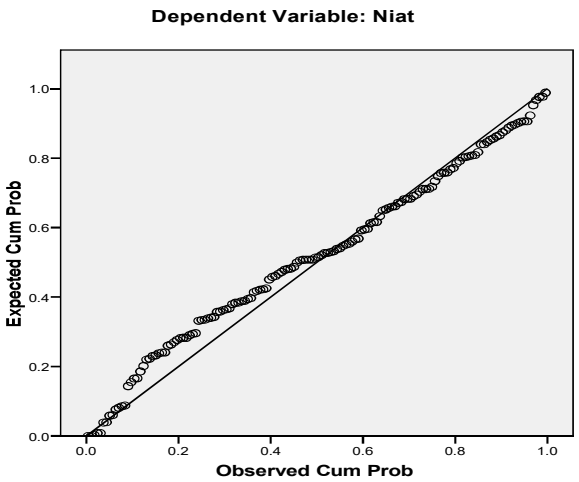

Gambar 2

Grafik Normal Probability Plot

Dari grafik normal probability plot di atas dapat disimpulkan bahwa data (titik) menyebar disekitar garis diagonal dan mengikuti arah garis diagonal menunjukkan pola distribusi normal, sehingga dari grafik di atas menunjukkan bahwa model regresi memenuhi asumsi normalitas.

\section{Uji Multikolinearitas}

Dalam penelitian ini, pengujian multikolinieritas didekati dengan nilai VIF (Variance Inflation Factor). Santoso (2006) menyatakan "jika VIF lebih besar dari 10 maka variabel tersebut diyakini mempunyai persoalan multikolinieriatas dengan variabel bebas yang lainnya".

Tabel 3 Uji Reliabilitas

\begin{tabular}{lll}
\hline Model & Tolerance & VIF \\
\hline (Constant) & & \\
Sikap & 0,825 & 1,087 \\
Norma Subyektif & 0,917 & 1,122 \\
Halal Image & 0,816 & 1,017 \\
\hline
\end{tabular}

Sumber : Data Primer 2019 (diolah)

Dari tabel di atas dapat disimpulkan bahwa tidak adanya multikolinieritas antar variabel yang diteliti. 


\section{Analisis Regresi Linier Berganda}

Untuk mengetahui pengaruh Sikap, Norma Subyektif, Dan Halal Image terhadap Niat Konsumen, maka dilakukan analisis data melalui formulasi regresi linear berganda (multiple regression). Hasil output regresi linier berganda dapat dilihat pada tabel berikut :.

Tabel 4 Analisis Regresi Linear Berganda

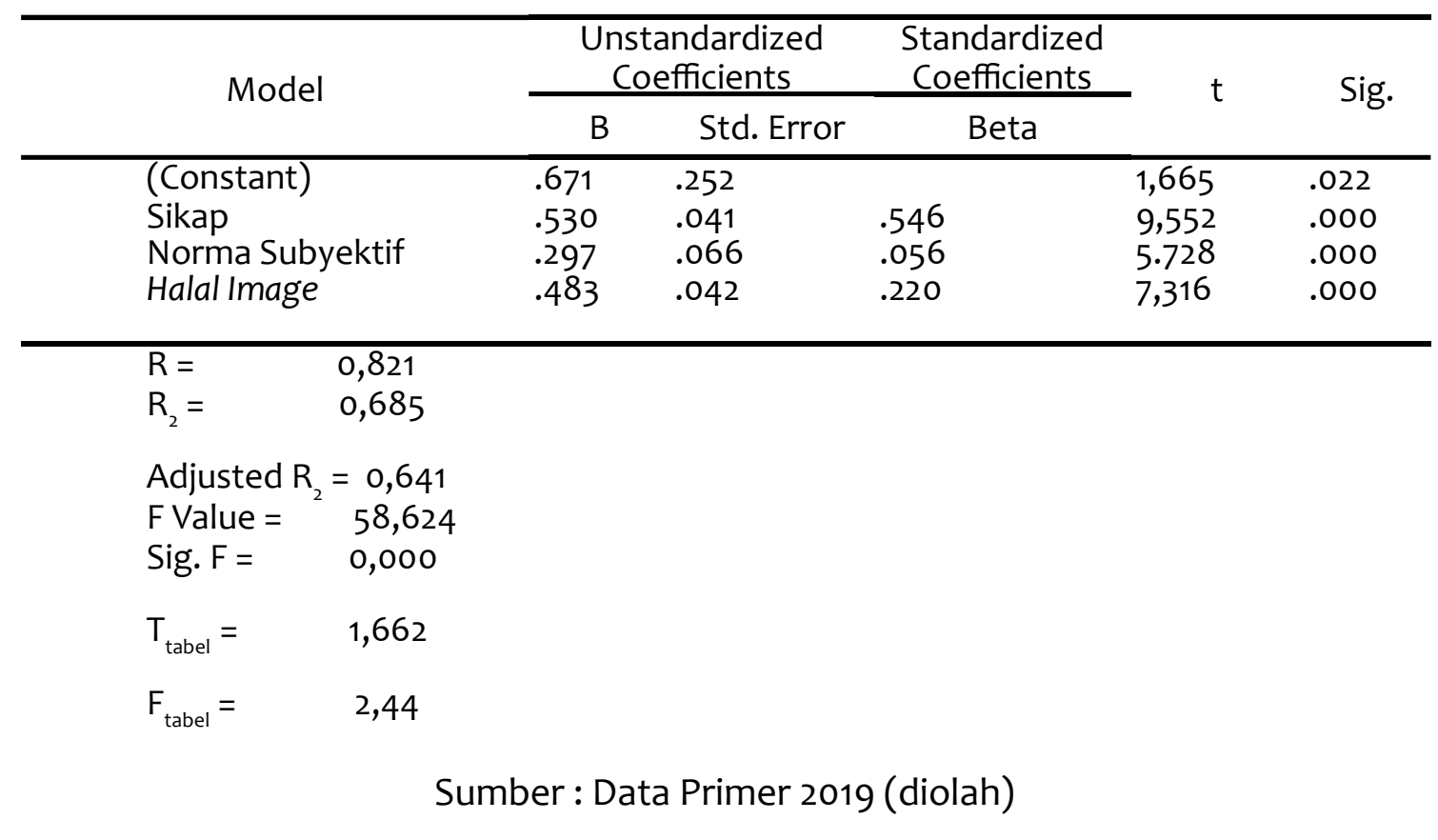

Berdasarkan hasil analisis model regresi Tabel 4 di atas, maka dapat disusun persamaan regresi sebagai berikut :

$$
\mathrm{Y}=0,671+0,530+0,297+0,483
$$

Berdasarkan dari persamaan di atas dapat diketahui bahwa Koefesien regresi dari variable Sikap adalah sebesar 0,530, variable Norma Subyektif sebesar 0,297, dan variable Halal Image 0,483, Koefesien regresi dari variable Sikap lebih besar dibandingkan dengan koefesien regresi variable lainnya, hal ini menunjukkan bahwa variable Sikap paling dominan mempengaruhi Niat Konsumen.

Dari table 4 di atas juga dapat dilihat nilai dari koefesien korelasi yang menjelaskan hubungan antara variable bebas yaitu Sikap, Norma Subyektif, dan Halal Image dengan variable terikat yaitu Niat Konsumen. Nilai korelasi adalah sebesar 0,821 atau $82,1 \%$ sehingga dapat dikatakan variable bebas mempunyai korelasi yang kuat dan positif terhadap variable bebas.

Nilai koefesien Determinasi yang diperoleh adalah sebesar 0,685 atau 68,5 \%. 
Angka ini menunjukkan kontribusi variable bebas dalam mempengaruhi variable terikat, sedangkan 31,5\% pengaruh terhadap variable terikat dijelaskan oleh variable lain di luar model penelitian ini.

\section{Uji Simultan (Uji F)}

Uji ini dilakukan dengan menggunakan uji signifikan simultan yaitu uji $F$, untuk menujukkan apakah variabel bebas (independen) secara bersama-sama mempunyai pengaruh terhadap variabel terikat (dependen). Dari Tabel 4 dapat diketahui bahwa nilai $\mathrm{F}$ hitung sebesar 58,624 Sedangkan $\mathrm{F}$ table sebesar 2,44 pada tingkat signifikansi ? $=5 \%$. Hal ini memperlihatkan, bahwa berdasarkan perhitungan uji statistik menunjukkan bahwa nilai $\mathrm{F}$ hitung $\geq \mathrm{F}$ tabel, dengan tingkat probabilitas 0,000. Dengan demikian hasil perhitungan ini dapat diambil suatu keputusan bahwa secara simultan variabel Sikap, Norma Subyektif, dan Halal Image berpengaruh dan signifikan terhadap Niat Konsumen

\section{Uji Parsial (Uji T)}

Secara parsial variabel Sikap berpengaruh secara signifikan terhadap variabel Niat Konsumen. Hal ini dapat dilihat pada tabel 4 di atas yang menunjukkan T hitung $(9,552)>$ dari pada $T$ tabel $(1,662)$ dan dengan tingkat signifikansi alpha di bawah 0,05 (5\%) sebesar 0,000. Dengan demikian maka hipotesis alternatif 1 yang di ajukan diterima.

Selanjutnya variabel Norma Subyektif secara parsial berpengaruh secara signifikan terhadap variabel Niat Konsumen. Hal ini dapat dilihat pada tabel 4 di atas yang menunjukkan $T$ hitung $(5.728)>$ dari pada $T$ tabel $(1,662)$ dan dengan tingkat signifikansi alpha di bawah 0,05 (5\%) sebesar 0,000. Dengan demikian maka hipotesis alternatif 2 yang di ajukan diterima.

Variabel Halal Image secara signifikan berpengaruh terhadap variabel Niat Konsumen. Hal ini juga dapat dilihat pada tabel 4 di atas yang menunjukkan $\mathrm{T}$ hitung $(7,316)>$ dari pada $T$ tabel $(1,662)$ dan dengan tingkat signifikansi alpha di bawah 0,05 (5\%) sebesar 0,001. Dengan demikian maka hipotesis alternatif 3 yang di ajukan diterima.

Dari hasil analisis uji secara parsial dapat diketahui bahwa variabel Sikap lebih besar kontribusinya dalam mempengaruhi Niat Calon Nasabah menggunakan produk perbankan syariah pada Bank Negara Indonesia Syariah (Bnis) cabang Lhokseumawe dibandingkan dengan variabel Norma Subyektif dan Halal Image. Hal ini menunjukkan konsumen cenderung memposisikan sikapnya terlebih dahulu dalam menentukan $\mathrm{Ni}$ atnya untuk menggunakan produk perbankan syariah pada Bank Negara Indonesia 
Syariah (Bnis) cabang Lhokseumawe.

\section{SIMPULAN}

Penelitian ini bertujuan untuk menganalisis Berdasarkan hasil penelitian yang dilakukan, maka dapat diambil kesimpulan antara lain sebagai berikut.

1. Berdasarkan hasil uji parsial variabel Sikap merupakan variabel yang paling dominan berpengaruh terhadap Niat Calon Nasabah menggunakan produk perbankan syariah pada Bank Negara Indonesia Syariah (Bnis) cabang Lhokseumawe

2. Variabel Norma Subyektif dan Halal Image juga berpengaruh signifikan terhadap Niat Calon Nasabah menggunakan produk perbankan syariah pada Bank Negara Indonesia Syariah (Bnis) cabang Lhokseumawe tetapi tidak begitu dominan jika dibandingkan dengan pengaruh dari variabel Sikap

\section{PUSTAKA ACUAN}

Ajzen, I., \& Fishbein, M., (1975), "Belief, attitude, intention, and behavior: An introduction to theory and research", Reading, MA: Addison.Wesley.

Ajzen, Icek dan Driver, B.L. (1991) "Prediction of Leisure Participation from Behavioral, Normative and Control Beliefs: An Application of Theory of Planned Behavior". Leisure Sciences, Vol. 13, 185 - 204

Ajzen, I., \& Cote, N, G., (2008), "Attitudes And Attitude Change”, Published in : W. D. Crano \& R. Prislin (eds), (pp. 289-311), Psychology Press, New York

Ali, A., Xiaoling, G., Sherwani, M. and Ali, A. (2018), “Antecedents of consumers' Halal brand purchase intention: an integrated approach", Management Decision, Vol. 56 No. 4, pp. 715-

Birn, Robin J (2000) "The International Handbook of Market Research Technique" In association with the Market Research Society (Kogan Page), London.

Dharmmesta, Basu Swastha (1998) Theory Of Planned Behavior Dalam Penelitian Sikap, Niat, dan Perilaku Konsumen. KELOLA Volume 18 Nomor 7

Ghozali, Imam, 2009. "Aplikasi Analisis Multivariate Dengan Program SPSS”, Edisi Keempat, Penerbit Universitas Diponegoro.

Kaakeh, A., Hassan, M. and Van Hemmen Almazor, S. (2019), "Factors affecting customers' attitude towards Islamic banking in UAE", International Journal of Emerging Markets, https://doi.org/10.1108/IJOEM-11-2017-0502. Emerald Publishing Limited.

Kotler, Philips Dan Gary Amstrong, (2008). “Dasar-Dasar Pemasaran”, jilid I, Penerbit 
PT. Indeks, Jakarta.

Lada, S., Harvey Tanakinjal, G. and Amin, H. (2009), "Predicting intention to choose halal products using theory of reasoned action", International Journal of Islamic and Middle Eastern Finance and Management, Vol. 2 No. 1, pp. 66-76.

Ma'ruf, Jasman J, (2005) “Riset Perilaku Konsumen (Niat Membeli Melalui Internet)”, MM-USK, Banda Aceh.

Mowen, Jhon C \& Minor, Michael (2001) “Perilaku Konsumen”, Jilid 1-2, Jakarta : Penerbit Erlangga

Mohd Suki, N. and Abang Salleh, A. (2016), "Does Halal image strengthen consumer intention to patronize Halal stores?", Journal of Islamic Marketing, Vol. 7 No. 1, pp. 120-132.

Mohd Suki, N. and Abang Salleh, A. (2018), "Mediating effect of Halal image on Muslim consumers' intention to patronize retail stores", Journal of Islamic Marketing, Vol. 9 No. 2, pp. 338-355.

Peter, J.P., and J.C., Olson (2000), "Consumer Behavior and Marketing Strategy", McGraw-Hill Inc.: Singapore.

Santoso, Singgih, (2006), “Menguasai Statistik di Era Informasi dengan SPSS 14”, PT. Elex Media Komputindo, Jakarata

Schiffman, L.G. and L.L. Kanuk (2004), “Consumer Behavior”, 7th ed., New Jersey: Prentice Hall International, Inc.

Sigit, Murwanto, (2006) Pengaruh Sikap Dan Norma Subyektif Terhadap Niat Beli Mahasiswa Sebagai Konsumen Potensial Pasta Gigi Close Up. JURNAL SIASAT BISNIS Volume 11 Nomor 1.

Sugiyono. (2013). “Metode Penelitian Kuantitatif, Kualitatif dan R \& D”. Alfabeta: Bandung. 